This item was submitted to Loughborough's Research Repository by the author.

Items in Figshare are protected by copyright, with all rights reserved, unless otherwise indicated.

\title{
A review of manufacturing re-shoring in the context of customer-focused postponement strategies
}

PLEASE CITE THE PUBLISHED VERSION

http://dx.doi.org/10.1177/0954405415623486

\section{PUBLISHER}

(C) Institution of Mechanical Engineers

VERSION

AM (Accepted Manuscript)

\section{PUBLISHER STATEMENT}

This work is made available according to the conditions of the Creative Commons Attribution-NonCommercialNoDerivatives 4.0 International (CC BY-NC-ND 4.0) licence. Full details of this licence are available at: https://creativecommons.org/licenses/by-nc-nd/4.0/

\section{LICENCE}

CC BY-NC-ND 4.0

\section{REPOSITORY RECORD}

Moradlou, Hamid, and C.J. Backhouse. 2019. "A Review of Manufacturing Re-shoring in the Context of Customer-focused Postponement Strategies”. figshare. https://hdl.handle.net/2134/20547. 


\title{
A review of manufacturing re-shoring in the context of customer focused postponement strategies
}

\author{
Hamid Moradlou \\ Wolfson School of Mechanical and Manufacturing Engineering, Loughborough University, Loughborough, UK \\ Chris J Backhouse \\ Wolfson School of Mechanical and Manufacturing Engineering, Loughborough University, Loughborough, UK
}

\begin{abstract}
For more than half a century, offshoring has been a trend amongst many industry sectors and all company sizes which are aiming to expand business by reducing costs and accessing foreign markets. However in recent years, the evidence indicates that offshoring strategies may no longer continue to provide the same level of benefits for organizations' manufacturing activities. Companies have begun to establish a better understanding of the total risk/benefit-balance and base their supplier decisions on strategic supply chain issue rather than simply relying on cost analysis. Hence it is evident that there are tendencies to reverse the off-shoring strategy and re-shoring manufacturing activities back to the home country. Despite the significance of this phenomenon to manufacturing, the supply chain literature has focused predominantly on the macro economic analysis whilst the literature on the operational aspects of re-shoring is relatively sparse. The first half of this paper aims to address the first research question which identifies the operational motivations behind the re-shoring phenomenon. This is done by studying the current literature available on the context of re-shoring. The second half of the paper determines the feasibility of a manufacturing strategy, "Postponement", as a possible solution for the companies to adjust and cope with the volatile customer demands and new generation of technologies towards more responsive production and customizable products
\end{abstract}

\section{Keywords}

Re-shoring, supply chain management, reinvented manufacturing 


\section{Introduction}

In today's internationalized world, manufacturing enterprises are obliged to operate within far more complicated and longer supply chains than in the past. Businesses are forced to structure their supply chain around global configurations [1] in order to access cheap labour, raw materials, larger markets and to take advantage of the incentives offered by the host governments for foreign investments [2], [3]. Consequently the trend for expanding and contracting across the globe has become popular across all industries with the aim of ultimately reducing the production costs and gaining competitive advantage. This involves strategic planning in terms of sourcing from locations that offer the lowest procurement rates, moving manufacturing and assembly to the low-cost countries and finally marketing in regions that have the highest potential customer demands [4].

As a result, western industries started to shift their production to the low-cost countries, i.e. Eastern Europe and Asia, in the 1990s, as an activity which is commonly known as "Offshoring" [5], [6]. This trend began by moving the low-skilled jobs such as simple assembly processes for high volume commodity type products to the developing countries. However with the help of communication technologies and easier access to educational 
channels, these developing countries are now capable of providing a far more sophisticated labour force. As a result of this, there has been a dramatic decrease in manufacturing jobs in some of the developed countries such as USA, Germany, France and UK [7], [8], [9].

However according to Fine [10] during recent years "the big names at the end of the chain have come to realize that the lowest price can mean highest risk - and highest risk can mean high total costs". Therefore when it comes to manufacturing location decisions industries have begun to pay more attention to unexpected factors such as the supply chain reliability issue and strategic factors rather than simply considering unit part cost [8], [11]. Additionally the issue of brand reputation and the risk to companies of being exposed in the transparent global supply chains imposes greater ethical and long-term manufacturing location decisions [12]. Having considered the discrepancy between the initially estimated cost of offshoring and those actually incurred from the unexpected costs, it is evident that there are tendencies on reversing the off-shoring strategy [13], [14], [15], [16]. This has led companies to perform rigorous risk analysis considering total cost and to take the supply chain perspectives into account when making manufacturing location decisions. They no longer rely solely on cost aspects of the production [17]. Nonetheless it is essential for the 
company to perform an in-depth research to identify the risks associated with their location decision as well as outsourcing and insourcing strategies.

It is evident both in the literature as well as the media that the industries and jobs that are returning to the developed countries will be different to the ones that were previously offshored i.e. mainly labour intensive activities [10], [18], [19]. Due to these changes it is believed that the only way for a long lasting and a sustainable re-shoring strategy is fundamental transformation of the current industrial production [20], [21], [22]. In a report written by Tata Consultancy Service [23], these transformations are called "Reinvented Manufacturing”. Meanwhile PA manufacturing group claim that quality and costs issues are unlikely to be the reason for the long-term repatriation of production from low cost countries [20]. Consequently seven mega-trends were recommended by Tata Consulting Service [23] to be adopted as a new direction of manufacturing industries. These megatrends are:

1. 'Consumerization' of manufacturing - from B2B to B2B2C,

2. Virtualization and digitization for all - Global collaboration from product design to customer service, 
3. Supply chain network economy for better management of $\mathrm{B} 2 \mathrm{C}$ aspiration,

4. Complexity reduction and modularization of business,

5. Product design, material science, and sustainability,

6. Next Gen technology - Hybrid crossover solutions,

7. Evolution of the manufacturing model.

This emphasizes the significance of integrating the new generation of technologies within manufacturing activities that are being re-shored. In addition to reviewing the operational motivations behind the re-shoring phenomenon, the study reported in this paper investigates the relationship between re-shoring phenomenon and the emerging trends in the context of supply chain management. The research aim is to determine from the literature the feasibility of a manufacturing strategy, "Postponement", as a possible solution for the companies to adjust and cope with the volatile customer demands and new generation of technologies towards more responsive production and customizable products.

\section{Re-shoring/Back-shoring}

In recent years, companies have begun to establish a better understanding of total cost and base their manufacturing location decisions on supply chain issue and strategic factors 
rather than simply relying on unit part cost [17]. For this reason the decision on reversing the previous offshoring strategy has gained substantial momentum. However, despite the significance of this phenomenon, the supply chain literature has not received sufficient attention by the academics [12]. In this section a comprehensive literature review is included. In order to do so, search tools such as "google scholar", "research gate" and "web of science" were used to access journal papers and also media and magazines were reviewed for latest news on the subject. Due to the immaturity of the concept, several names have been dedicated in the existing literature such as "on-shoring", "back-shoring, "back-reshoring", "home-shoring", "re-distributed manufacturing" and "repatriating manufacturing" [24], [8], [25]. It should be noted that each of the above phrases are used in different countries, for instance re-shoring is mainly used in USA and UK [21], [12] whereas backshoring and back-reshoring are used in Germany and Italy [26], [8].

Among the research done on the context of re-shoring in the literature, Kinkel and Maloca [24] have carried out an investigation by conducting a survey that covers 1663 German companies providing a representative data base for all the manufacturing sectors. Similarly Tate [27] studies reshoring movement in the United State by analysing 319 American companies that have been already involved in a offshoring decision. The results achieved in 
the current study uses the outcome from aformentioned studies and suggest a manufaturing strategy which could accommodate the challenges faced by the companies in the new era of manufacturing.

It is evident in the literature that reversing the offshoring decisions is not necessarily a new phenomenon. There have been number of studies performed under different titles such as "De-internationalization" and "International divestment". Benito and Welch [28] define De-internationalization as any activities, voluntary or compulsory, that decreases a company's engagement in present cross-border activities. The analysis was carried out from three theoretical perspectives: economic, strategic management and internationalization management. The concept of International divestment defines the reduction of level of ownership in company's direct foreign investment regardless of decision voluntariness [29]. However these concepts, De-internationalization and International divestment, lack some of the key features of re-shoring such as outsourced production. In addition these studies do not particularly consider the relocation of facilities back to the home country.

One of the most recent studies that investigate the reversal of offshoring decisions was conducted by Gray et al., [13]. In this American based study the term "re-shoring" was used 
where the major emphasis was on the location decision and their consequences on manufacturing companies. According to Gray et al., [13] "Re-shoring, as such, is fundamentally concerned with where manufacturing activities are to be performed, independent of who is performing the manufacturing activities in question - a location decision only as opposed to a decision regarding location and ownership" [13]. Moreover it is emphasized that the re-shoring should be assessed as a reversion of a prior offshoring strategy rather than in isolation. Another study, using the term re-shoring, was undertaken by Ellram et al., [17] where re-shoring is defined as "moving manufacturing back to the country of its parent company". This study likewise uses the data from a survey among American companies to explore the reasons that influence the organization's manufacturing location decision in the United States. In order to establish better understanding of the location assessment, the factors influencing these decisions according to various regions were investigated. The results obtained from this study states that the importance of supply chain characteristics varies according to different regions across the globe. However it is important to note that the findings in this study only focuses on the wholly owned manufacturing facilities in foreign locations and does not address the scenarios such as reshoring products that were previously outsourced to other foreign suppliers. 
The term "Back-shoring" is an alternative name frequently used in the recent literature to refer to re-shoring phenomenon. Kinkle and Maloca [24] are amongst the scholars that have made major contributions to this concept. According to Kinkle and Maloca [24], Backshoring is defined as process of returning full or part of the production from fully owned facilities in foreign locations or a foreign supplier to the company's domestic site. Unlike studies performed by other researchers, in this analysis, Kinkle and Maloca [24] claim "Back-shoring activities are predominantly short-term corrections of prior misjudgment in offshoring decisions rather than long-term adjustment to chaining conditions at the foreign location". This study was carried out based on the data obtained from German Manufacturing Survey 2006 (Fraunhofer Institute of System and Innovation Research). However one element that has not been mentioned in this German study is the voluntariness of the Back-shoring decision. For this reason, the study completed by Fratocchi et al., [8], which used the term "back-reshoring", proposes a unified and operative definition. According to this study Back-reshoring is "a voluntary corporate strategy regarding the home country's partial or total relocation of (in-sourced or out-sourced) production to serve the local, regional or global demand" [8]. In order to identify the main features of reshoring phenomenon, Fratocchi et al., [8] have used a comparative analysis of the reshoring definition found in the existing literature. As a result of this study, three main 
characteristics of re-shoring concept were found. Firstly, it is a decision to reverse a previous decision to offshore facilities. Secondly re-shoring can comprise only partial repatriation and does not imply closure of the entire production facilities in the offshored location. Thirdly re-shoring decision determines the relocation of the facilities back to the home country regardless of the ownership mode (In-sourcing and Out-sourcing) [8].

\section{Types of re-shoring}

The re-shoring phenomenon can occur independent of the facility ownership. This includes both in-sourced and outsourced productions. Therefore manufacturing re-shoring can be considered from company boundaries (in-sourcing and outsourcing) and geographical boundaries (home country and foreign country) perspectives [13]. As a result, four possible re-shoring strategies can be identified. These four strategies are different from each other but they share the element of location decision. These scenarios are listed below:

- In-house re-shoring, where companies supply their domestic market by repatriating the entirety or part of, their wholly owned manufacturing facilities from the foreign country to wholly owned facilities in the UK. 
- Re-shoring for outsourcing, where companies supply their domestic market by shifting the manufacturing activities from wholly owned manufacturing facilities from the offshored location to a UK based supplier.

- Re-shoring for insourcing, where companies supply their domestic market by changing the companies sourcing strategy from offshored suppliers to wholly owned manufacturing facilities in the home country.

- Outsourced re-shoring, where companies supply their domestic market by converting their supply mode from offshored suppliers to UK-based suppliers [13].

\section{Motivations for re-shoring}

According to [30] most offshoring decisions are taken without evaluating a clear picture of total costs versus total benefits. This leaves the companies with the problem of facing various costs also mentioned as "hidden costs" by various scholars [12], [31]. Figure 1 illustrates the main motivations behind the re-shoring decisions and identifies 'hidden costs'. After a comprehensive literature review the costs were classified into two main categories namely the expected and unexpected costs [32], [26], [13], [12], [17], [31], [8], [33], [21].

Figure 1, Expected and Unexpected costs associated with manufacturing location decisions 
The diagram captures the variety of elements studied in the re-shoring literature and provides a big picture of costs that potentially lead to failure of a manufacturing location decision. The left hand side shows the factors which are distinctive to any relocation strategy and the companies can have an approximation of the costs associated with them. One of the noteworthy direct factors imposing a change on the off-shoring trend was the transportation costs and volatile fuel price [34], [35]. This made the transportation cost more important relative to other costs such as inventory, production and facility fix costs [36]. Moreover, with the adoption of slow steaming practices for the shipping industry, to reduce the fuel oil costs, the global supply chain slowed down considerably [37]. The longer the supply chains become the transfer of goods get slower and therefore ultimately leading to an increase in the capital required as well as the risk of on time delivery. Clearly in 2015 the reduction in the oil price will again change the impact of this factor however it is too early to see the effect of this on res-shoring decisions.

On the other hand the reinforcement on the environmentally concern legislations specifically on the carbon emission, has placed an unprecedented pressure on the transportations costs [17]. Another potential cost is the dramatic increase in the labour cost in the low-wage countries. This is considered to be the next important factor influencing 
offshoring decisions. Wage rate differential between western countries and countries in fareast Asia, was one of the critical drivers for the offshoring decisions. However this gap is gradually decreasing as the wages are rising due to the higher expectations of labour and continues strikes due to lack of attention to working conditions [6].

One example of labour strike occurred in Honda, which led to $47 \%$ increase in wages of Chinese employees in 2010 [25]. Furthermore according to [38], the difference between the labour productivity ratio in Western countries and Asia is another contributor that supports re-shoring strategy. Meanwhile the unexpected travel costs can impose substantial costs on the company during the transition stage when the program managers, team leaders and the business owners need to be frequently present at the offshore location [6]. In this early stage, the experienced members of the organisation are required to be travel to the low cost country to provide sufficient amount of training to the less experienced workers on the site [30].

The second category consists of the expenses that are not easy to quantify and require rigorous risk analysis. These costs normally play very important role in manufacturing location decisions since the companies will learn about them after starting to offshore [13] and also are listed among the top motives behind the re-shoring decisions [39], [40]. The 
first major issue regarding the offshoring is the inconsistency in the quality of the products. According to the survey carried out by EEF in 2014 [39], the quality appears to be the predominant reason for the competitive advantage in the UK therefore maintaining the high quality is considered to be their primary goal. In addition, the study performed by [13] shows this by empirically assessing the difficulties in controlling a series of factors that can potentially affect quality in offshore manufacturing and the absence of accessible measures that are consistent across geographic regions. The next common problem associated with offshoring is the miscommunications. This can be seen in terms of misunderstood requirements, design mistakes and problems with the phone systems and language barrier that can cause frustrations during the calls. Nevertheless this can be considered as one of the main reasons for quality issues.

Offshoring can also reduce the flexibility of the production to address the issues related to the fast changes in market condition. By locating the manufacturing facilities closer to the end customer, quicker responses to the changes can be ensured due to shorter supply chains and better understanding of the market (Gray et al., 2013). This also enhances the capability of the company to recover in the case of any disruption in the supply chain [38]. In addition, the problems caused by the time differences between the countries can be 
eliminated since the major part of the supply chain is located in one geographical location. Another significant drawbacks related to moving the business abroad, is the protection of sensitive information. Despite of having laws to protect the intellectual properties in countries such as China, the confidential data about innovative and new products are still vulnerable being exposed in a foreign market [17], [25]. Another contributor to the unquantifiable costs is the cultural differences between the targeted country and the home country. These differences appear to be greater in Eastern Asian countries. Examples include diverse attitude on the product quality as well as the value perceived. In addition, different countries adopt different approaches on the communications and negotiations [30].

The middle section represents the costs that can be calculated but are not entirely under control of the companies. These factors are strongly influenced by the governmental decisions and political situations.

However according to the study done by [31], the significance of these costs influencing the re-shoring decisions, varies according to different countries. For instance in the past two years, ongoing studies have been performed to investigate the feasibility of the re-shoring strategy within the UK. Based on the latest Manufacturing Advisory Service Barometer, the 
costs, quality and reducing delivery time were recognized to be the main three reasons, driving the re-shoring decisions in the UK [41]. Factors for French companies appear to be different to that of the UK. According to Clever Age [40] the most important factors for the French industries were the transport and operational costs followed by the quality and lack of internal competence [42], [40]. However Figure 1 shows the factors that can be applied in the majority of the companies regardless of where the companies are based. According to the case studies done by Engineering Employers Federation (EEF) [39], Martin Rubber Company was one of the examples of businesses that witnessed the difficulty in sourcing

from low-labour cost countries. This company is involved in providing design and development service to the customers who were using overseas suppliers in China. Nevertheless Martin Rubber Company is seeing a steady flow of companies looking for alternative UK suppliers due to reasons such as long lead times, inconsistence product quality, and communication breakdown with the foreign suppliers [39].

\section{Nature of new technologies coming back}

In today's world, manufacturing industry is experiencing a significant change in business ecosystem as a result of ever-increasing complexity in customer behavior, technological development as well as competitive environment [43], [44], [45]. Due to these reasons PA 
Consultancy Group claims that quality and costs issues are unlikely to be the reason for the long-term repatriation of production from low cost countries [20]. Instead it is believed that the only way for a long lasting and sustainable re-shoring strategy is fundamental transformation of the current industrial production, which is also called "Reinvented Manufacturing". In other words, it will not be economically feasible to repatriate the same manufacturing tasks that were previously offshored due to factors such as high labor and energy content. Therefore the new generation of manufacturing activities is required to adopt modern technologies by which industries will ensure their competitive position in the market. One of the major focuses in the concept of Reinvented Manufacturing is the personalization of the product by moving from mass production towards mass customization in order to address the ever-changing customer expectations. By doing so the industries can achieve higher variety while keeping the volume low.

According to the PA Consulting Group the reinvention of manufacturing will provide new business opportunities and models for the home based local manufacturer. Among these new technological opportunities, big data, intelligent robots, Additive Manufacturing (AM), self-assembly Nano machines, utilization of new materials such as nanotechnologies, cyber materials and green plastics were mentioned [20]. Meanwhile another study conducted by 
Tata Consultancy Service (TCS) [23] states that the future of manufacturing needs to be aligned with seven mega trends in order to address problems caused by the evolving technological landscape. These mega trends are as follow:

- Consumerization of manufacturing. In other words shifting the focus from Business-to-Business (B2B) to Business-to-Business-to-Consumer (B2B2C). This involves the establishment of customer-centric business system using interactive websites, digital marketing channels, Point-of-Sale (POS) systems, e-commerce.

- Virtualization and Digitization. This comprises the utilization of software to simulate, visualize, and virtualize the product behaviour and performance under virtual scenarios. Hence it enables the companies to achieve more products testing iteration within a shorter time resulting in a quicker time-to-market. The Cloud technologies can be considered as one of the way to initiate such collaborations between companies.

- Connected Supply Chain. A network of interrelated supply chain that can also provide high visibility from suppliers to distributors. This would allow the 
companies to develop an agile production plan meanwhile maintain minimum inventory.

- Complexity Reduction and Modularization of Business. Modularization can be applied in various aspects of the business, products as well as processes. For instance by adopting standardization and harmonization, companies can ensure component economies of scale since similar components across product families will be used which also facilitates product updating. Moreover it increases the product variety and also reduces the order lead-time due to fewer components.

- Product Design, Material Science and Sustainability. This trend investigates the application of the new generation of materials with higher performances, lower costs and environmentally friendly. Moreover, companies are also obliged to consider the carbon footprint from supply perspective by intelligent sourcing and shortening the supply chains.

- Next Gen Technology. This includes the utilization of embedded electronics, telematics, mobility, telecom services, and conventional engineering systems. 
- Evolution of the manufacturing model. This indicates the requirement for a shift from large centralized companies to a network of smaller modularized businesses that offer their core competencies and are closer to the end customers [23].

In accordance with these mega trends, in modern manufacturing, organizations should collaborate globally in order to cope with the dramatic changes in the market [46]. Physically distributed manufacturing architecture is an essential element in achieving this goal that allows the organizations from different locations to contribute their main capabilities into the business [47]. However the utilization of the local suppliers also plays a substantial role to increase the awareness about domestic markets and facilitate production responsiveness. The temporary alliance of these businesses can be managed by utilization of systems that integrates all the organizations involved in the business. Such objectives can be achieved through virtual enterprises which are collaborative networks of businesses that share their core competencies in order to pursue a mutual goal to respond to business opportunities. For instance, in such collaboration, an organization takes the responsibility of product design whilst the other provides the manufacturing data supports [48]. In order to develop a virtual enterprise and distributed manufacturing architecture, it is vital for the business to establish an appropriate partnership with the involving partners at the right location (offshore or onshore) to ensure the fastest respond to the market changes. 
The establishment of the rapid partnership, OEMs, Tire 1, 2, 3 and $\mathrm{N}$ supplier is based on the partner's delivery capabilities, the quality of the products, infrastructure and the level of their dependability on IT, which can also relate to the next generation trends, mentioned previously. The key objectives of forming a rapid partnership would be to integrate the technical knowledge with the market knowledge in order to remain competitive against other manufacturing organizations [49]. As a result of these mega-trends mentioned previously, the business processes should be transformed in order to adapt to the new technological changes, organizational policies should be reconsidered and meanwhile the people are expected to think and perform differently to these transformations [23]. The following section represents a framework, which can potentially link the challenges associate with the re-shoring decisions to the next generations of manufacturing strategies through implementation of postponement approach.

\section{Postponement in the context of Re-shoring}

Once the repatriation of the manufacturing activities back to the home country has occurred, the companies are required to develop an effective management strategy for their new supply chain layout that can creatively integrate and perform logistics and production

activities [21], [50]. Meanwhile, customers demand for higher levels of product 
customizations have put the manufacturing industries under substantial cost pressures in order to cope with shorter product lifecycles [51], [52]. This requires accurate planning and product demand forecast. However this task is becoming more complex with higher risks. Hence the alternative supply chain strategy called Postponement is being widely used to minimize the issue caused by the uncertainties [53], [54]. Despite the maturity of the postponement concept in the academic world, its application in the industries is still limited [55], [53]. Postponement was initially viewed, in marketing literature, as a strategy to reduce the risk and uncertainty costs associated with the differentiation (form, place, and time) of goods [56].

According to Yang and Burns [53] "postponement centers around delaying activities in the supply chain until real information about the markets are available". This strategy can be applied in product design, process design and supply chain management [57]. There are numerous studies completed, investigating different aspects of postponement both in business and marketing as well as production management literature and earlier studies date back to 1950 [56], [58], [59]. These studies mainly identify where, when and how to implement the postponement strategy [60]. On the other hand more recent studies such as "Capturing Value from Global Network" mentions late customization as one of the four 
meta-capabilities that involves aligning companys' strategies with possible supply network configuration models and network capability [61]. Therefore it is evident that the application of the postponement is expected to increase during the coming years within the industries [62], [61], [63].

In addition this is further emphsised when Elite Electronic System Ltd, a UK based company providing contract electronic manufacturing service to custormers overseas, states that long lead times, inconsistant quality, increase in shipping time and difficulties in communications as their main reasons for re-shoring their production activities from China to the UK [39]. It appeared that the enlogated supply chain made the coordination with suppliers and customers more difficult than before. Once the production was repatriated Elite has more control and better visibility over its supply chain.

Figure 2 illustrates the overall structure of how the re-shoring phenomenon can be linked to the postponement strategy while the new generations of technologies are emerging. This diagram is the outcome of an extensive literature review on re-shoring and postponement strategy and series of meetings hold with Engineering Employers Federation (EEF), UK Trade and Investment (UKTI) and TATA consultancy service as well as OEMs such as 
Jaguar and Land Rover (JLR). After identifying the gap in the literature, the framework for the future research was developed. The Re-shoring concept has received significant attention from business perspectives but the technical aspect and practical guideline for industries is still in its infancy. As it is shown in the diagram the re-shoring can face manufacturing and business oriented challenges. The business-oriented challenges include areas such as macroeconomics, political issues, tax and tariffs and governmental incentives. These factors are currently being studied by a number of scholars and governmental organizations [64], [21], [17], [27], [65], [22]. Therefore this leaves the gap to investigate the manufacturing side of this phenomenon. The manufacturing challenges faced by the companies who are re-shoring can fall into three categories, supply, operational and demand [66].

Supply: In order to be aligned with the current business environment, companies are required to improve their organizational infrastructure and manage their business processes effectively [67]. Recent studies show that to gain global competitiveness, companies should integrate and coordinate their production operations [68] with their suppliers through a concept called triple-A supply chains [69]. A triple-A supply chain encompasses the Agility, Adaptability and Alignment [70], [69], [71]. According to Lee [69] "agility is the 
ability to respond to short-term changes in demand or supply quickly [and] handle external disruptions smoothly". Hence the supply chain should be able to respond to sudden disruptions such as geopolitical tensions, natural disasters and product recalls [69]. With the expanding global economy, companies are obliged to also emphasize on adaptability in order to cope with ever increasing dynamics related to supply and establish a trustworthy supply network. And the third factor on supply side is the alignment. Lee [69] defines alignment as capability of the companies to align the interest of all their participating firms in the supply chain $\left(1^{\text {st }}, 2^{\text {nd }}\right.$ and $3^{\text {rd }}$ Tier suppliers $)$ with their own interests.

Operational: These challenges can appear in various areas such as production, $\mathrm{R} \& \mathrm{D}$, logistics, marketing and sales, finance and purchasing [72]. However the new business environment continues to create new challenges that requires companys' strategic planning [61], [73]. The authors believe that the evolution of technological landscape forces reorientation of business processes across industries in order to accommodate any changes in business behaviors. Therefore, the shift in the way that manufacturing industry operate can significantly influence the industries that are re-shoring or planning to re-shore their facilities. The operational challenges faced by the companies can directly relate to TCS viewpoint on seven mega-trend impacting manufacturing world [23]. These seven mega- 
trends, are the key areas that needs to be improved at the operational level throughout the entire supply chain. It is notable that the implications of these trends are to minimize the uncertainties associated with demand fluctuation by emphasizing on customization, modularization and complexity reduction. This is where the postponement approach, in other words late customisation, can be adopted to prevent the failure of re-shoring decisions [61], [20] and reduce supply chain complexity [74]. It is evident in the literature that postponement can offer different type of proactive approaches to overcome the uncertainties through product development postponement, purchasing postponement, production postponement and logistic postponement [75], [76]. Therefore postponement can be introduce at the operational level where it can relate to agility, alignment and adaptability of supply side and the responsiveness of the demand side by being able to adopt engineering to order, purchasing to order, making to order, final assembly to order, packaging to order and finally shop to order [60]. The outcome of this investigation suggests that the re-shoring phenomenon provides a very possitive platform for companies that are repatriating their production lines. It also aids the development of new supply chain configurations to adopt postponement strategy whilst utilising new generation technologies. This can be done at the early stages of supply chain design by utilizing the responsiveness of the local supply network while capturing the global efficiency. Hence it is believed that 
postponement can be used as a tool in order to link the customer demand to the manufacturing operations while accommodating new trends required for the future generation of businesses such as customization, digitization, modularization, standardization and forming a connected supply chain. However the outcome of this research is based on the existing literature and can be validated by conducting a survey study so a more generalisable data can be collected.

Figure 2, Framework linking operational challenges in re-shoring to new era of manufacturing through postponement strategy

\section{Conclusion}

Over the past few years manufacturing industry has witnessed a considerable revolution in the way that this industry operates. One of the most recent production strategies used in western countries such as USA, Germany, France and UK is re-shoring strategy. Reshoring is currently receiving significant attention by the media as well as academic environment. This is due to the urgent requirement to meet the customer specifications and survive in a dynamic business environment. As a result of this a new generation of technologies and business models are being developed to substitute the previously offshored manufacturing activities. 
This study contributes to the body of knowledge by investigating the nature of re-shoring trend and the 7 mega-trends in manufacturing industries. Different types of re-shoring were identified which were "in-house re-shoring", "re-shoring for outsourcing", "re-shoring for insourcing", "outsourced re-shoring" .The reasons behind the re-shoring decision were also divided into two groups, namely expected and unexpected factors. Since re-shoring involves repatriating the manufacturing activities to the home country, the companies are required to develop a new supply chain configuration using local suppliers. This provides the platform to implement production strategies such as postponement in the case of the products that require shorter lead-time. Hence in this paper, postponement is recommended as a possible solution for the companies that are re-shoring to the UK. This is in order to align the company strategies and the emerging concepts such as late customization. The introduction of the postponement concept in re-shoring companies can reduce the delivery time and help companies be more responsive, which is currently one of the main reasons behind re-shoring strategy. 


\section{Bibliography}

[1] Chandraprakaikul, W; Baines, T. S; Lim, R. Y; , "Strategic positioning of manufacturing operations within global supply chains," Proc. IMechE Vol. 224 Part B: J. Engineering Manufacture, 2009. 831-848

[2] Manuj, I; Mentzer, J; , "Global Supply Chain Risk Management," Journal of Business Logistics, 2008. 133-156

[3] Roza, M; Van den Bosch, F. A; Volberda, H. W; "Offshoring strategy: Motives, functions, locations, and governance modes of small, medium-sized and large firms," International Business Review, 2011. 314-323

[4] AlHashim, D. D;, "Internal Performance Evaluation in American Multinational Enterprises," Management International Review (MIR), 1980.

[5] Corino, R;, "Offshoring, Multinationals and Labour Markets: A review of the emperical literature," Journal of Economic Surveys, 2009. 197-249

[6] neoIT, "Total Cost of Offshore (TCO): Understanding The True Offshore Financial Rewards and Costs," Offshore insights white papers series, 2004.

[7] Herath , T; Kishore, R;, "Offshore Outsourcing: Risks, Challenges, and Potential Solutions," Information Systems Management, 2009. 312-326

[8] Fratocchi, I., Mauro, C., Barbieri, P., Nassimbeni G., and Zanoni, A., "When Manufacturing Moves Back: Concepts and questions," Journal of Purchaing and Supply Management, 2014. 54-59

[9] Tate, W. L; , "Offshoring and Re-shoring: US insights and research challenges," Journal of Purchasing and Supply Management, 2014. 66-68

[10] Fine, C; , "Intelli-sourcing to replace offshoring as supply chain transparency increases," Journal of Supply Chain Management, 2013. 6-7

[11] Moser, H;, "Time to come home?," Supply Chain Quarterly, 2011.

[12] Ellram, L; , "Offshoring, Reshoring and Manufacturing location decision," Journal of Supply Chain Management Internationalization, 2013. 14-22

[13] Gray, J; Skowronski, K; Esenduran, G; Rungtusanatham, J;, "The reshoring Phenomenon: What Supply Chain Academics ought to know and should do," Journal of Supply Chain Management, 2013. 27-33

[14] Plumer, B; , "Is U.S. manufacturing making a comeback — or is it just hype?," 1 
May 2013. [Online]. Available:

http://www.washingtonpost.com/blogs/wonkblog/wp/2013/05/01/is-u-smanufacturing-set-for-a-comeback-or-is-it-all-hype/. [Accessed 6 Dec 2014].

[15] Bishop, M;, "Reshoring Garment Production: China to the United States," White Paper, 2011.1-22

[16] GOV, "New government support to encourage manufacturing production back to the UK," January 2014. [Online]. Available: https://www.gov.uk/government/news/new-government-support-toencourage-manufacturing-production-back-to-the-uk. [Accessed 22 March 2014].

[17] Ellram, L; Tate, W; Petersen, K; " "Offshoring and reshoring: an Update on the Manufacturing Location Decision," Journal of Supply Chain Management, 2013. 14-22

[18] Bardhan, A; , "Will Reshoring And Hi-Tech Boost Jobs? It's Doubtful," 17052014. [Online]. Available: http://www.huffingtonpost.com/ashok-bardhan/reshoringjob-boost_b_4971870.html. [Accessed 2906 2014].

[19] Baxter, D;,"Reshoring: Back to the source," 12 May 2014. [Online]. Available: http://business-reporter.co.uk/2014/05/reshoring-back-to-the-source/. [Accessed 29 June 2014].

[20] Lawrence, T., Vasak, D., "Re-shoring Good, Reinvention Better: UK manufacturing need to take the long view," PA Manufacturing White Paper, 2014.

[21] Bailey, D., De Propris, L., "Manufacturing reshoring and its limits: the UK automotive case," Cambridge Journal of Regions, Economy and Society, 2014. 1-17

[22] Davies, P., Holweg, M., Huggett, N., Schramm, S., and Tran, Y., "Growing the automotive supply chainassessing the upstreamsourcing potential," Automotive Council UK, NOV 2014.

[23] Tata Consultancy Service, "Manufacturing Reinvented, How Technology is changing the Future of Manufacturing," White Paper, 2013.

[24] Kinkel, S; Maloca, S; , "Drivers and actecedents of manufacturing offshoring and backshoring- A German perspective," Journal of Purchasing and Supply Management, 2009. 154-165

[25] Tavassoli, S;",Manufacturing Renaissance: Return of manufacturing to western countries," CSIR Electronic Working Paper Series, 2013. 261-280

[26] Kinkle, S;,"Future and impact of backshoring-Some conclusions from 15 years of 
research on German practices," Journal of Purchasing \& Supply Management, 2014. 62-65

[27] Tate, W. L; Ellram L. M; Schoenherr, T; and Petersen, K. J; "Global competitive conditions driving the manufacturing location decision," Business Horizons , 2013. $1-10$

[28] Benito, G; Welch, L;, "De-Internationalization," Management International Review , 1997. 1-22

[29] Boddewyn, J J; Torneden, R; , "US foreign divestment: a preliminary survey," Columbia J. World Bus, 1973.

[30] Leibl, P; Morefield, R; Nischler, C; Pfeiffer, R; "An Analysis of Offshoring Manufacturing to Reduce Costs," Journal of Business and Behavioral Sciences, 2009. Volume 21

[31] Leibl, P., Morefield, R., Pfeiffer, R., "A study of effects of backshoring in the EU," Journal of Business and Behavioural Sciences, 2011. 130-139

[32] Kinkel, S; "'Trends in production relocation and backshoring activities. Changing patterns in the course of the global economic crisis," International Journal of Operations \& Production Management, 2011. 696-720

[33] Fratocchi, L;" Manufacturing Back-Shoring: A Research Agenda for an Emerging Issue in International Business," 37th European International Business Academy Annual Conference, 2011.

[34] Behar, A., \& Venables, A. J., "Transport costs and international trade," Handbook of Transport Economics, 2010. 1-25

[35] A. Kamyabniya and M. Fakhrzad, "Sustainability in supply chain with focus on efficiency, safety, and industrial emission factors," Proc IMechE Part B:J Engineering Manufacture, pp. 1-6, 2015.

[36] Simchi-Levi, D., "How volatile oil prices will rock the supply chain," CSCMP's Supply Chain Quarterly, 2011.

[37] Hull, B. Z., "Are supply (driven) chains forgotten?," International Journal of Logistics Management, 2005. 218-236

[38] Fishman, C., "The insourcing boom," December 2012. [Online]. Available: http://www.theatlantic.com/magazine/archive/2012/12/theinsourcingboom/309166/\#.UMJkUoG5d1w.mailto.. [Accessed 06 Feb 2014].

[39] EEF, "Backing Britain," EEF, London, 2014. 
[40] Clever Age Digital Architecture, "Offshoring/backshoring, l'art de tourner en rond?," August 2006. [Online]. Available: http://www.cleverage.com/veille/clever-link/offshoring-backshoring-l-art-de-tourner-en-rond. [Accessed 06 June 2014].

[41] MAS, "MAS Barometer," September 2013. [Online]. Available: http://www.mymas.org/news/mas-barometer-reveals-quality-cost-anddelivery-are-prime-drivers-to-move-production. [Accessed 24 March 2014].

[42] Bellego, C., " Reshoring: a multifaceted decision involving much more than just labour costs," direction générale de la compétitivitéde l'industrie et des services (dgcis), March 2014. 1-4

[43] Tang, O., Musa, S. N., "Identifying risk issues and research advancements in supply chain risk management," Int. J. Production Economics, 2010. 25-34

[44] Carter C. R., Easton, P. L., "Sustainable supply chain management: evolution and future directions," International Journal of Physical Distribution \& Logistics Management, 2011. 46-62

[45] Lee, H. L., Whang S., "E-Business and Supply Chain Integration," White Paper, 2001. 1-20

[46] Christopher, M., Towill, D., "An integrated model for the design of agile supply chains," International Journal of Physical Distribution \& Logistics, 2001. 235-246

[47] Cha, H. S., Pingry, D. E., and Thatcher, M. E., "Managing the Knowledge Supply Chain: An Organizational Learning Model of Information Technology Offshore Outsourcing," MIS Quarterly Vol. 32 No. 2, 2008. 281-306

[48] Ali U; Kidd,C;, "Configuration Management maturation: An empirical investigation," Proc IMechE Part B: J Engineering Manufacture, 2014, pp. 321-327

[49] Gunaskaran, A; "Agile manufacturing: enablers and an implementation framework," 1998. 1223-1247

[50] Pagh, J; Cooper, M; , "Supply Chain Postponement and Speculation Strategies: How to choose the right strategies," Journal of Business Logistics, 1998. 13-33

[51] Kundu, S., McKay, A., and Pennington, A. D., "Selection of decoupling points in supply chains using a knowledge-based approach," Proc. IMechE Vol. 222 Part B: J. Engineering Manufacture, 2008. 1529-1548

[52] Christopher, M., "The Agile Supply Chain. Competing in Volatile Markets," Industrial Marketing Management, 2000. 37-44 
[53] Yang, B; Burns, N;, "Implications of postponement for the supply chain," International Journal of Production Research ISSN, 2003. 2075-2090

[54] Zinn, W., Bowersox, D. J., "Planning Physical Distribution with the Principle of Postponement," Journal of Business Logistics, 1988. 117-136

[55] Battezzati, L; Magnani, R; "Supply chains for FMCG and industrial products in Italy practices and the advantages of postponement," International Journal of Physical Distribution and logistics Management, 2000. 413-324

[56] Alderson, W., "Marketing efficiency and the principle of postponement," Cost and Profit Outlook, 1950. 423-427

[57] Van Hoek, R I; Peelen, E; Commandeur, H R;, "Achieving mass customization through postponement: a study of international changes," J. Market Focused Manage, 1999. 353-368

[58] Bucklin,L. P., "Postponement, speculation and the structure of distribution channels," Journal of Marketing Research, 1965. 26-31

[59] Van Hoek, R. I., "The rediscovery of postponement a literature review and directions for research," Journal of Operations Management, 2001. 161-184

[60] Yang, B., Burns, N., Backhouse C. J., and I. Member, "The Application of Postponement in Industry," IEEE Transactions On Engineering Management, Vol. 52, No. 2, 2005. 238-248

[61] Srai, J., S., Christodoulou, P., "Capturing Value From Global Networks," IfM, Management Technology Ploicy Report Cambridge University, 2014.

[62] Yang, B; Burns, N D; Backhouse, C J;, "An empirical investigation into the barriers to postponement BIA0," International Journal of Production Research, 2004. 3741

[63] Hilletofth, P., "Differentiation focused supply chain design," Industrial Management and Data Systems, 2012.1274-1291

[64] Casson, M., "Economic Analysis of International Supply Chains: An International Perspectives," Economic Analysis of International Supply Chains, 2013. 8-13

[65] SMMT, "The Wright Rview of Manufacturing. The Cost Base of the UK Supply Chain Perspectives from Automotive Industries," The Societty of Motor Manufacturing and Traders , April 2014.

[66] Lambert, D. M., Cooper, M. C., "Issues in Supply Chain Management," Industrial Marketing Management, 2000. 65-83 
[67] Soni, G; Kodali, R;, "An empirical investigation of supply chain management excellence framework in Indian manufacturing industry," Proc IMechE Part B: J Engineering Manufacture, 2014. 1-22,

[68] Maginness, M; Shehab, E; Beadle, C; Carswell, M;, "Principles for aerospace Manufacturing Engineering in integrated New Product Introduction," Proc IMechE Part B: J Engineering Manufacture, 2013, 1-10

[69] Lee, H. L.,"The Triple-A Supply Chain," Harvard Business Review, 2004.

[70] Whitten, G. D., Green Jr, K. W., Zelbst, P. J., "Triple-A supply chain performance," International Journal of Operations \& Production Management, 2012. 28-48

[71] Ishaq, M., Khaliq, W., Hussain, M., Waqas, M., "A Review on Triple-A Supply Chain Performance," School of Doctoral Studies (European Union) Journal, 2012. 89-94

[72] Zhang, Y; Gregory, M; Shi, Y;, "Managing global engineering networks part II: Case studies and directions for the future research," Proc IMechE Part B: J Engineering Manufacture, 2014. 172-180

[73] Boone, C. A., Christopher, W., Craighead, and Hanna, J. B., "Postponement: an evolving supply chain concept," Internation Journal of Physical Distribution and Logistics Management, 2007. 594-611

[74] Zhou, D., "An Empirical Study of the Role of Postponement Application in Reducing Supply Chain Complexity," IEEE, 2002. 448-453

[75] Yang, B., Burns, N., Backhouse, C. J., "Management of uncertainty thtough postponement," International Journal of Production Research, 2004a. 1049-1064

[76] Ernst, R., Kamrad, B., "Evaluation of supply chain structure through modularization and postponement," European Journal of Operational Research, 2000. 495-510

[77] Porter, M., \& Rivkin, J., "Choosing the United states," Harvard Business, 2012.

[78] Swamidass, P. M.,"Empirical science: The new frontier in operations management," Acad. Manage. Rev, 1991. 793-814

[79] Dabbs, J. M., Making things visible, I. J. V. Maanen, Ed., CA: Beverly hills, 1982. 